\title{
FAMILY PROVISION, THE FAMILY FARM AND RURAL PATRIARCHY: THREE ACTORS IN SEARCH OF A PLAY?
}

\section{MALCOLM VOYCE*}

This article describes how rural claimants have had their claims dealt with under family provision legislation. This legislation provides that, where a testator does not provide adequate provision for the proper maintenance and support of certain dependants, the court in its discretion may make further provision out of the estate. As regards this legislation, this article concentrates on the expectations of farming sons who have worked on farms and who may expect to receive a major share of a family property. Their claim is compared against the claims of daughters and widows. The article contends that family provision legislation, which in many cases works to the advantage of farming sons, reflects forms of patriarchy which overlap with and incorporate rural ideas of labour and the place of women on farms.

\section{INTRODUCTION}

The first part of the article analyses the general objective of family provision, which in brief, is to remedy by way of 'curial intervention' ${ }^{1}$ the duty of a testator to provide for those who are dependent on him or her. While the legislation allows for a broad class of claimants, the article concentrates on the claims of farming sons who have worked on the farm. The second part of this article, through a sociological approach to law, examines ideas of rural patriarchy within farming communities. The article examines how family provision law overlaps and interlocks with rural culture by supporting ideas of masculine labour and the idea that men are the rightful inheritors of land.

\footnotetext{
* LLB (Auck), MA, PhD (Lond), PhD (Macq), Associate Professor, Law School, Macquarie University.

${ }^{1}$ Barns v Barns (2003) 214 CLR 169, 173 (Gleeson J).
} 


\section{A Family Provision, the Family Farm and Rural Patriarchy: Three Actors in Search of a Play?}

Scholars from a variety of traditions in both common law and civil law countries have had a long interest in the study of rural inheritance. ${ }^{2}$ One focus for both lawyers and sociologists has been the extent to which children may expect a share of the family estate. It is instructive to compare different inheritance systems. In the United States, parents may disinherit children, leaving them without a legal claim against their parents. ${ }^{3}$ By contrast, in civil law jurisdictions children are entitled to a fixed portion of an estate. ${ }^{4}$ Some Commonwealth countries, ${ }^{5}$ including Australia, follow a Testators' Family Maintenance system, or Family Provision system, which limits testamentary freedom. ${ }^{6}$ In this article the legislation is referred to as the 'Acts', by which expression is meant this legislation in general, regardless of the State or country to which it belongs.

In this system, testamentary freedom has been limited by the power of the courts to order that provision be made out of a deceased estate in favour of a

${ }^{2}$ See a classic collection of research on inheritance in rural society in Jack Goody, Joan Thirsk, and Edward P Thompson (eds), Family and Inheritance: Rural Society in Western Europe, 1200-1800 (Cambridge University Press, 1976). Different issues have emerged in rural inheritance studies, such as the impact of partible and impartible inheritances on social and economic life, social stratification, inheritance inequality and the exclusion of women from receiving property.

${ }^{3}$ Deborah A Batts, “'I Didn't Ask to Be Born”: The American Law of Disinheritance and a Proposal for Change to a System of Protected Inheritance' (1990) 41 Hastings Law Journal 1197; Joshua C Tate, 'Caregiving and the Case for Testamentary Freedom' (2008) 42 University of California Davis Law Review 129.

${ }^{4}$ As regards the Italian legal system, see Leroy Certoma, The Italian Legal System (Butterworths, 1985) 376 ff. As regards other European countries, see David Hayton (ed), European Succession Laws (Jordans, $2^{\text {nd }}$ ed, 2002).

${ }^{5}$ The other jurisdictions that have these laws are New Zealand, Canada (except Quebec) and England (including Northern Ireland).

${ }^{6}$ The various Acts and Ordinances are: Family Provision Act 1969 (ACT); Succession Act 2006 (NSW); Family Provision Act (NT); Succession Act 1981 (Qld); Inheritance (Family Provision) Act 1972 (SA); Testator's Family Maintenance Act 1912 (Tas); Administration and Probate Act 1958 (Vic); Family Provision Act 1972 (WA). Dower was abolished in Australia: Dower Act 1836, 7 Wm IV No 8. On the question of dower, see also in NSW the Real Estate of Intestates Distribution Act 1862, 26 Vic No 20 and Andrew Buck, "'A Blot on the Certificate": Dower and Women's Property Rights in Colonial New South Wales' (1987) 4 Australian Journal of Law and Society 87. Standard works on family provision include: Leonie Englefield, Australian Family Provision Law (Lawbook, 2011); John K de Groot and Bruce W Nickel, Family Provision in Australia and New Zealand (Butterworths, 2012); Rosalind Atherton and Prue Vines, Australian Succession Law: Commentary and Materials (Butterworths, 2013); Gino Dal Pont and Ken Mackie, Family Provision in Australia (LexisNexis, 2012). 
certain class of dependants if the court is satisfied that adequate provision has not been made for an applicant.

The way that rural claimants under Australian family provision legislation have had their claims dealt with has been well described elsewhere. ${ }^{7}$ The range of applicants for family provision typically includes former spouses, married daughters and farming sons. It is well known that in Australian family provision cases, those sons who have worked and continue to work on the family farm are well rewarded. This article gives an overview of the cases to demonstrate how rural ideas on inheritance and gender, as a particular form of rural ideology, are reflected in judicial decision making.

Accordingly, the first part of the article analyses the general objective of family provision and the treatment in law of applications by farming sons. The second part, through a sociological approach to law, examines ideas of rural patriarchy within farming communities. It concludes that the adequacy of awards to farming sons coincides with a form of patriarchy on farms, which endorses the supremacy of male labour and the attitude that men should inherit the family farm. At the same time, the article comments on how decisions on family provision law interlock with ideas of rural patriarchy.

A short description of family farming in Australia commences the analysis and highlights several features of family farming pertinent to this article.

\section{B Gender Issues and the Family Farm: How Work is Evaluated and Inheritance Portions Calculated}

Rural sociologists have dealt extensively with the numerous social and legal aspects of family farming in Australia, including the decline of farm numbers, the increasing age of the farmer population, the availability of health services, transport, and the disproportionate incidence of suicide in farming populations. ${ }^{8}$

\footnotetext{
${ }^{7}$ Englefield, above n 6, 150-3; De Groot, and Nickel, above n 6, 60-8; Malcolm Voyce, 'The Impact of Testator's Family Maintenance Legislation as Law and Ideology on the Family Farm' (1993) 7 Australian Journal of Family Law 191 and Malcolm Voyce, 'Testamentary Freedom, Patriarchy and Inheritance of the Family Farm in Australia' (1994) 34 Sociologia Ruralis 1.

${ }^{8}$ For greater specificity of detail, see Australian Bureau of Statistics, Australian Farming and Farmers (December 2012) <http://www.abs.gov.au/AUSSTATS/abs@.nsf/Lookup/4102. 0Main+Features10Dec+2012>. See also Neil Barr, The House on the Hill: The Transformation of Australia's Farming Communities (Land and Water Australia in association with Halstead Press, 2009); Margaret Alston, 'Who Is Down on the Farm? Social Aspects of Australian Agriculture in the 21st Century' (2004) 21 Agriculture and Human Values 37; Ian Gray and Geoffrey Lawrence, A Future for Regional Australia: Escaping Global Misfortune (Cambridge
} 
Another issue is the survival of the family farm under capitalism. Some scholars have seen the survival of the farm in western economies as a refutation of Marxist theory, which predicted the ending of family farming. ${ }^{9}$ Other scholars have argued that the family farm has survived because of its capacity to continue operating for minimal rewards as compared with industrialised agriculture. ${ }^{10}$ Recently, it has been asked in Australia whether overseas interests should be allowed to buy rural property. These debates will not be dealt with in the present article except by reference to the literature on the topic.

However, two issues remain of concern. One is the extent to which farming sons receive the larger share of the farm through inheritances. Rural sociologists regard farm labour as gendered in several ways. ${ }^{11}$ First, males and females perform different tasks. In most cases, men have been seen to perform physical work and women to perform domestic work. Second, work performed by men has been more highly valued. Third, men typically determine what work women perform. Fourth, women's contributions are usually regarded as secondary or are labelled as 'helping out'. ${ }^{12}$

Recently, feminist scholars have developed a more nuanced reading of this account. These studies have shown that women have in some cases resisted

University Press, 2001) and Richard Sappey et al, 'Succession Planning in Australian Farming' (2012) 6(4) Australasian Accounting, Business and Finance Journal 94. More references on the social aspect of agriculture are cited later in $\mathrm{n} 100$.

${ }^{9}$ Karl Marx, Capital: A Critique of Political Economy (International Publishers, 1974) 614-39. The literature in traditional rural sociology has been reviewed succinctly and critically by Harold Newby, 'The Rural Sociology of Advanced Capitalist Societies' in Harold Newby (ed), International Perspectives in Rural Sociology (New York, 1978) 3.

${ }^{10}$ David Goodman and Michael Redclift, 'Capitalism, Petty Commodity Production and the Farm Enterprise’ (1985) 25 (3-4) Sociologia Ruralis 231; Michael Winter, 'Agrarian Class Structure and Family Farming' in Tony Bradley and Philip Lowe (eds), Locality and Rurality; Economy and Society in Rural Regions (Geo Books, 1984) 91; Sarah Whatmore, Farming Women: Gender, Work and Family Enterprise (Macmillan, 1991). For a good summary see Fiona Williams, The Family Farm through a Succession Lens: Towards Understandings of Contemporary Practices and Processes (Doctoral Thesis, University of Aberdeen, 2010).

${ }^{11}$ Barbara Pini, "We Could Have Had the Old Girl Out in the Paddock Years Ago": Widowed Women, Farming and Agricultural Leadership’ (2003) 17(1) Work, Employment and Society 171. Other seminal work on this topic includes Margaret Alston, 'Farm Women and Their Work: Why It Is Not Recognised?’ (1998) 34(1) Journal of Sociology 23; Margaret Alston, Breaking through the Grass Ceiling: Women, Power and Leadership in Rural Australia (Harwood Publishers, 2000); Sally Shortell, Women and Farming: Property and Power (Macmillan, 1999) and Sarah Whatmore, Farming Women: Gender, Work and Family Enterprise (Macmillan, 1991).

${ }^{12}$ Pini, above n 11. 
such stereotypes by formulating alternative discourses. ${ }^{13}$ This crossing over of gender boundaries illustrates that there is no 'homogeneous femininity', as gender identities are not singular but are multiple and varied. ${ }^{14}$

For instance, many women help the family business by developing careers outside agriculture, enabling them to forge new identities and social connections. This employment may cause family income to flow away from farm development towards family consumption and so ultimately negate the otherwise positive impact of this 'outside' work on the farm business.

Pini and Price, in their study on tractor work on sugar farms, have demonstrated that women negotiate new strategies in order to reassert and maintain their femininity when they cross boundaries and drive tractors on the farm. ${ }^{15}$ The authors describe how women hide their work on the farm by driving tractors only around the back of the farm so neighbours will not see them. ${ }^{16}$ In other ways such women may strongly emphasise that their domestic roles are paramount and a means to support their spouses. They may also form strategies to achieve an acknowledgement of the idea of male (spouse) supremacy by giving considerable attention to their dress and by distancing themselves from other men with whom they work who show strong masculine behaviour. By these means, they affirm male hegemony. ${ }^{17}$

However, these strategies offer little challenge to the gendered division of labour. In reality, such activities may reinforce and sustain it. The fact is that the construction of farming as a masculine endeavour has proved 'highly resilient' in the face of feminist or modern ideals. ${ }^{18}$

As regards inheritance of farming property, especially among the older generation, succession is generally considered to have been governed by patriarchy, meaning that masculine values determine who inherits the farm. ${ }^{19}$

\footnotetext{
${ }^{13}$ Janine Liladhar, 'From the Soap Queen to the Aga-Saga: Different Discursive Frameworks of Familial Femininity in Contemporary Women’s Genres’ (2000) 9(1) Journal of Gender Studies $5,11$.

${ }^{14}$ Barbara Pini and Robin Price, 'Gender Identity and Women's Involvement in Tractor Work: A Case Study of the Australian Sugar Industry’ (2005) AIRAANZ 449, 450.

${ }^{15}$ Pini and Price, above n 14.

${ }^{16}$ Ibid.

${ }^{17}$ Ibid 455.

${ }^{18}$ Ibid.

${ }^{19}$ Ruth Gasson, 'The Role of the Farmer's Wife in Australia' in The Women in Country Australia Look Ahead (McMillan Rural Studies Centre, 1979) 35; Ruth Gasson and Andrew Errington, The Farm Family Business (CAB International, 1993); Linda Price and Nick Evans, 'From “As Good
} 
Nowadays, however, 'taking on the family farm' is not a moral obligation as it once may have been, as parents recognise the greater opportunities that modern society offers to their sons. ${ }^{20}$

The most recent research indicates that most farming parents prefer a male successor. Alston reports that daughters inherit only five per cent of farms, ${ }^{21}$ indicating that farming sons are the preferred inheritors of family land. While it is suggested in this article that farming values are implicitly male, commentators have noted that daughters are sometimes well rewarded for helping ageing parents, that frequently daughters receive pre-inheritances through tertiary education support, and that 'gold-digging' daughters-in-law often succeed in getting a generous amount of farming property. ${ }^{22}$ However, it is suggested here that these considerations do not detract in general from the supremacy of patriarchy as regards rural succession.

\section{The General Objectives of Family Provision LEGISLATION}

Family provision legislation imposes a legal obligation on testators or testatrixes to make proper provision for the support and maintenance of certain defined dependants. ${ }^{23}$ Should a testator or testatrix fail to make such provision in his or her will, or should intestacy provisions fail to provide for such a dependant, the aggrieved dependant may apply for an order varying the terms of the will or varying the statutory rules on intestacy. The family provision Acts do not empower the court to make a new will for the testator. Courts only alter a will (or the effect of intestacy provisions) as far as is necessary to provide for

as Gold" to "Gold Diggers": Farming Women and the Survival of British Family Farming' (2006) 46(4) Sociologia Ruralis 280.

${ }^{20}$ For UK evidence, see Williams, above n 10; Price and Evans, above n 19. As regards Norway, see Mariann Villa, 'Born to be Farmers? Changing Expectations in Norwegian Farmers' Life Courses’ (1999) 39(3) Sociologia Ruralis 328. For Australia see Elaine Barclay, Roslyn Foskey and Ian Reeve, Farm Succession and Inheritance: Comparing Australian and International Trends (RIRDC Report, 2007).

${ }^{21}$ Alston, Breaking through the Grass Ceiling, above n 11, 37.

22 Price and Evans, above n 19, 288, 291.

${ }^{23}$ Eligible dependants are defined by the respective state and territory laws and ordinances. As regards NSW, see s 57 of the Succession Act 2006 (NSW). Note that in NSW the list of eligible claimants has been expanded to include a wider variety of claimants, such as a person, even if unrelated to the deceased, who was totally or partially dependent on the deceased at any time. Another category of claimants includes persons in a close personal relationship, where one provides domestic support and care. See ss 57(e) and 57(f) respectively of the Succession Act 2006 (NSW). 
the proper maintenance and support of dependants where adequate provision has not been made for this purpose. ${ }^{24}$

Scholars who have examined the introduction of family provision legislation have assumed that it was enacted to deal with aberrant testators. For instance, family provision has been described as a 'targeted response to ensure proper provision has been made according to the moral responsibility reposed in the testator' ${ }^{25}$ It is a 'curial intervention' where moral obligations of support have been discarded. ${ }^{26}$

\section{A The Original Rationale for Family Provision Legislation}

The first version of this type of legislation in was passed in New Zealand, as a response to the concern that families were left destitute when male breadwinners bequeathed their property to 'outsiders' (non-family members) such as the church or charities, without first adequately providing for their families. This situation was exacerbated by the poor chance that widows had of earning a living. ${ }^{27}$ Concern was also felt that destitute families would become a burden on the state. ${ }^{28}$

Another reason for the introduction of the legislation was the consideration that widows who had assisted their late husbands to accumulate property should be rewarded for their efforts after their husbands' deaths. This was perhaps not seen so much as rewarding those who stood on an equal footing with their husbands, but as rewarding ‘deserving' wives for good and faithful conduct. ${ }^{29}$

In Australia there were similar concerns, as evidenced by the first Australian Act in this area, namely the Widows and Young Children Maintenance Act 1906 (Vic). Another concern of those promoting the legislation in Australia was the

\footnotetext{
${ }^{24}$ Allardice; Allardice v Allardice (1910) 29 NZLR 959, 969 (Stout CJ). Although the range of applicants has been enlarged since Stout made this comment, the thrust of the comment is still true as to the overall limit of the discretion.

${ }^{25}$ See Dal Pont and Mackie, above n 6, 491.

${ }^{26}$ Barns v Barns (2003) 214 CLR 169, 173 (Gleeson J).

${ }^{27}$ Rosalind Atherton, 'New Zealand's Testators' Family Maintenance Act of 1900 — The Stouts, the Women's Movement and Political Compromise' (1990) 7(2) Otago University Law Review 202, 217 and Rosalind Atherton, 'The Testator's Family Maintenance and Guardianship of Infants Act 1916 (NSW): Husband's Power v Widow's Right' (1990) 6 Australian Journal of Law and Society 97.

${ }^{28}$ Atherton, 'New Zealand's Testators' Family Maintenance Act of 1900', above n 27, 218.

${ }^{29}$ Grainer, above n 27, 142-4.
} 
possible impoverishment of dependant relatives. The proposed reforms were intended to provide a mechanism for ensuring that testators met the needs of their dependant relatives so as to relieve the state or the community of that burden. ${ }^{30}$

Frequently it was argued by parliamentarians involved in advocating this legislation that a wife had a moral right to support where the wife had contributed to the estate:

It is a terrible thing that when a woman has worked for a lifetime to make a home, and to help her husband to get some property together, he should have the power, when perhaps he is a little bit silly in his old-age, or when he is led astray by somebody else, to will away the property that really belongs to his widow. ${ }^{31}$

\section{B The Traditional Approach to Family Provision Legis/ation}

Croucher has argued that family provision legislation (and the cases interpreting the legislation) developed an approach which required judges to assess what a just and wise husband and father would have done in the same circumstances. Family provision legislation did not represent a reduction of testamentary power but rather the devolution of it. ${ }^{32}$ Instead of liberation from patriarchy, it was merely a reformation of it.

Croucher ${ }^{33}$ argues:

[T] his was not recognised at the time, which reveals the narrowness of the perspective on the relevant issue. It was still locked into the idea of the sanctity of property rights and hence any incursion into them was seen as a considerable development. Although the Testator's Family Maintenance Act (NSW) represented a qualification to some extent on the exercise of testamentary powers, its key points were thoroughly consistent with the nineteenth century logic of property. The husband as property owner should be able to exercise his powers of discrimination through the use of his

\footnotetext{
${ }^{30}$ Atherton, above n. 27.

${ }^{31}$ New South Wales, Parliamentary Debates, Legislative Assembly, 17 October 1905, 2889 (Mr Booth).

${ }^{32}$ Rosalind Atherton, 'Will Drafting for De Facto and Second Marriage Partners' in Paul Cooper (ed), De Facto Second Marriage Partners: Inter Vivos Claims, Wills and Testamentary Disputes (Blackstone Press, 1992) 2, 56.

33 Prior to 2004, Croucher was known as Atherton.
} 
testamentary powers, and only where the Court considered that he erred in the allocation of his bounty should there be any intervention. ${ }^{34}$

The Croucher argument is applicable in the rural context, as generally the Acts did not interfere with the patriarchal values of farming. The Acts allowed male will makers to support masculine ideologies of who should get what; in effect the idea was undisturbed that farming sons' should inherit the family farm.

The concern about who should properly receive an inheritance was part of a larger preoccupation of the state with regulating the internal conduct of members of a family who owned property. ${ }^{35}$ The governance of property relations was not perceived merely to be concerned with social control and the regulation of property owners. Rather, with the advent of 'new liberalism' ${ }^{36}$ as a guiding principle, such governance was seen as necessary to encourage wayward members of the community, such as those who showed a lack of capacity to work, were intemperate or who did not properly take financial responsibility for each other, to provide properly for their dependants. ${ }^{37}$

On a superficial level, family provision legislation was neutral to the wish of rural farmers to maintain property in the hands of a son. The Acts did not direct the formal retention in the family of one form of property (such as a farm) against another. If a farm must be sold to provide for maintenance, that was

\footnotetext{
${ }^{34}$ Atherton, above n 32, 56. See also Rosalind Croucher, 'How Free Is Free? Testamentary Freedom and the Battle between "Family" and "Property" (2012) 37 Australian Journal of Legal Philosophy 9, 11.

${ }^{35}$ Gregory S Alexander, 'The Social-Obligation Norm in American Property Law' (2009) 94(4) Cornell Law Review 745, 747; Gregory S Alexander 'Governance Property' (2012) 160(7) University of Pennsylvania Law Review 1853.

${ }^{36}$ At the turn of the nineteenth century, following growing agitation for change in the position of women and a shift from the strictness of laissez faire and with the growth of the belief that the state should enter the private realm to protect weaker members. Richard Bellamy, 'Introduction' in Victorian Liberalism: Nineteenth-century Political Thought and Practice (Routledge, 1990) 1011.

${ }^{37}$ In the Australian parliamentary debates as regards what became known as family provision legislation and in the reports of Magistrates' courts it was commonly claimed that there was a solemn obligation resting upon a parent to provide for children, and for the children to relieve the necessity of the parent. It was argued in such debates that to interfere with that obligation was to seriously undermine the moral fibre of the community: Christina Twomey, Deserted and Destitute: Motherhood, Wife Desertion and Colonial Welfare (Australian Scholarly Publishing, 2002) 11-12. On how marriage was seen as an economic partnership, see New South Wales, Parliamentary Debates, Legislative Assembly, 17 October 1905, 2887, 2889 (Mr Arthur Griffith).
} 
seen as unavoidable. ${ }^{38}$ Thus, on one level of analysis, family provision legislation did not detract from or support the strong rural ideas that farms should not be divided and should remain as viable units. ${ }^{39}$

In the New Zealand context Peart argues that family provision legislation ${ }^{40}$ introduced one hundred years ago can now be seen as guaranteeing a right of inheritance to members of an immediate family and in particular to the children of the deceased. ${ }^{41}$

In Australia Croucher argues family provision legislation is expanding as more claimants 'claw back, more property; to override a testator's wish to limit provision'. Such developments she argues 'represents an overriding of the individual testator's judgment with respect to the property of his or her particular family'. ${ }^{42}$

Two other commentators, namely Myles McGregor-Lowndes and Frances Hannah, indicate that perhaps 'testamentary freedom is now an illusion', as jurisprudence in this area has developed to the point where disinheritance is almost impossible within a family circle if recourse is had to mediation or the courts under this legislation'. ${ }^{43}$

\section{Family Provision Law in Operation}

As indicated above, family provision law empowers a court to alter, or extinguish testators' intentions in order to provide for support for a family member where moral rights and obligations, and obligations of support, have been disregarded. ${ }^{44}$

\footnotetext{
${ }^{38}$ Bryant v Bryant (Unreported, Supreme Court of NSW, Needham J, 24 July 1986) 8, and see Worthington v Dickson (Unreported, Supreme Court of Western Australia, Brinsden J, 1 June 1984).

${ }^{39}$ Farmers do get some special concessions as regards stamp duty and tax in general as well as the benefits of 'rural restructuring' in the form of special grants and tax concessions. These benefits are not taken into account in many cases.

${ }^{40}$ In New Zealand, the legislation is called the Family Protection Act 1955.

${ }^{41}$ Nicola Peart, 'New Zealand Report on New Developments in Succession Law' (2010) 14(2) Electronic Journal of Comparative Law 1, 19-21.

${ }^{42}$ Rosalind Croucher, 'Contracts to Leave Property by Will and Family Provision after Barns $v$ Barns (2003) 196 ALR 65 — Orthodoxy or Aberration?’ (2005) 27(2) Sydney Law Review 263, 287.

${ }^{43}$ Myles McGregor-Lowndes and Frances Hannah, 'Reforming Australian Inheritance Law: Tyrannical Testators vs Greying Heirs?’ (2009) 17 Australian Property Law Journal 62, 62-3.

${ }^{44}$ Barns v Barns (2003) 214 CLR 169, 173 (Gleeson CJ).
} 
Under such legislation a court may make an order for the 'adequate provision for the proper maintenance, education or advancement in life ${ }^{45}$ of persons related to the testator by blood or by a close relationship of dependence. ${ }^{46}$ Each family provision Act contains a list of eligible claimants. ${ }^{47}$

The courts have developed a guiding principle that measures the standards of a testator against those of a supposed just and wise testator who acts in accordance with 'community standards'. In the words of Stephen J in White $v$ Barron,

this jurisdiction is pre-eminently one in which the trial judge's exercise of discretion should not be unduly confined by judge-made rules of purportedly general application. A trial judge has to place himself in the position of the testator and to consider what that testator 'ought to have done in all the circumstances of the case' .... No doubt this requires him to recognize and to apply prevailing community standards of what is right and appropriate since it is by those standards that the content both of the moral duty owed by a just husband and father to his wife and children and of departures from it will be measured. ${ }^{48}$

Such support is not designed to effect a fair distribution of an estate or to reward family members for services. In reaching decisions concerning family provision, the courts have to consider the various statutory considerations as specified in the various Acts. For instance, in New South Wales some of these considerations are specific factors relevant to the rural context, such as the size of the estate, the means and financial circumstances of the applicant, the relationship of the applicant to the deceased, the age and health of the applicant and the services rendered by the applicant to the deceased. ${ }^{49}$ While these factors are relevant in other contexts as well, the above mentioned factors play an important role in farming cases.

Family provision legislation has been regarded as addressing 'twin tasks'. The first is to determine whether the applicant has been left without adequate

\footnotetext{
45 This wording is from the Succession Act 2006 (NSW) s 59(1)(c). For comparisons of the wording of the various Acts see de Groot and Nickel, above n 6, 8.

${ }^{46}$ For a definition of 'eligible persons' in the see Succession Act 2006 (NSW) s 57(1).

${ }^{47}$ As regards NSW, see the Succession Act 2006 (NSW) s 57. Note that in NSW the list of eligible claimants has been expanded: see above $\mathrm{n} 23$.

${ }^{48}$ White v Barron (1980) 144 CLR 431, 440 quoting Bosch v Perpetual Trustee Co Ltd (1938) AC 463, 478. On the question of 'community standards' generally see Rosalind Atherton, 'The Concept of Moral Duty in the Law of Family Provision - A Gloss or a Critical Understanding?'(1999) 5(1) Australian Journal of Legal History 5, 14.

${ }^{49}$ See Succession Act 2006 (NSW) s 60(2).
} 
provision for his or her proper maintenance, education and advancement in life. The second task relates to the discretionary question of whether provision ought to be made and, if so, to what extent. ${ }^{50}$ It is clear that the court does not have power to rewrite the will. ${ }^{51}$ It should also be recognised that 'intervention should only be to the minimum extent necessary to make adequate provision for the proper maintenance, education and advancement of an applicant'. ${ }^{52}$

When the need of an applicant is to be assessed, terms such as 'adequate', 'proper' and 'need' must be understood in a broad sense. ${ }^{53}$ As expressed in $R e$ Leonard:

It must be shown that in a broad sense the applicant has need of maintenance and support. But an applicant need not be necessitous in circumstances: the size of the estate and the existence of any other moral claims on the testator will be highly relevant. ${ }^{54}$

The first few cases on the family provision Acts decided that the courts should place themselves in the position of the testator and consider whether he or she had been in breach of a moral duty As was expressed in Allardice; Allardice $v$ Allardice:

It is the duty of the court, so far as is possible, to place itself in all respects in the position of the testator, and to consider whether or not, having regard to all the existing facts and surrounding circumstances, the testator has been guilty of a manifest breach of that moral duty which a just, but not a loving, husband or father owes towards his wife or towards his children, as the case may be. ${ }^{55}$

After this classic formulation, some later judges described this moral duty approach 'may well be understood as amounting to a gloss on the statutory

\footnotetext{
${ }^{50}$ Affirmation of this approach is found in Singer v Berghouse (1994) CLR 201, 209-10 (Mason CJ, Deane and McHugh JJ); Vigilio v Bostin (2005) 221 CLR 191, 197 (Gleeson J), 218 (Gummow and Haynes JJ), 227 (Callinan and Heydon JJ).

${ }^{51}$ Pontifical Society for the Propagation of the Faith $v$ Scales (1961-2) 107 CLR 1, 19 (Dixon J).

${ }^{52}$ Permanent Trustee Co Ltd v Fraser (1995) 36 NSWLR 24.

${ }^{53}$ What is described here as 'adequate' and 'proper' maintenance is described in different ways in the various Acts. See de Groot and Nickel, above n 6, 8 for a description of the various sections of the Acts.

${ }^{54}$ [1985] 2 NZLR 88, 92. This New Zealand case was decided under similar legislation.

55 [1910] 29 NZLR 959, 972-3 (Edwards J).
} 
language'. ${ }^{56}$ Any obscurity has now been resolved by Vigolo $v$ Bostin as the High Court there decided to affirm the moral duty test in the following terms:

It remains of value, and should not be discarded. Such considerations have a proper place in the exposition of the legislative purpose, and in the understanding and application of the statutory text. They are useful as a guide to the meaning of the statute. They are not meant to be a substitute for the text. They connect the general but value-laden language of the statute to the community standards which give it practical meaning. In some respects, those standards change and develop over time. There is no reason to deny to them the description 'moral'. 57

\section{The Farming Sons Cases}

Sons frequently help build up a family farm. ${ }^{58}$ The family farm contains not only the family home and the place of socialisation for children into their various roles as farmers or non-farmers, but is also a means of social placement, which establishes social status, which may be passed on through social inheritance. The work of sons, as revealed in the farming cases, may take several forms. Frequently a son will leave school early and join his father after an agricultural or trade course. Sons are subsequently trained by their fathers to be farmers. In many cases an applicant may have helped build up the assets of the farm, frequently doing much of the heavy work for long hours for a low wage, while the father continues to hold the purse strings. ${ }^{59}$ The work of daughters is marginalised or forgotten. ${ }^{60}$ At the same time, parents often create

\footnotetext{
${ }^{56}$ Singer v Berghouse (1994) 181 CLR 201 (Mason CJ, Deane and McHugh JJ).

${ }^{57}$ Vigolo v Bostin (2005) 221 CLR 191, 204-5 (Gleeson CJ). See also Callinan and Heydon JJ at 230.

${ }^{58}$ Under the family provision legislation, the court may take into account any provision made for an applicant during his/her lifetime. Thus, any benefits such as education or equipping for life are taken into account. See Ian Hardingham, Marcia Neave and Harold Ford, Wills and Intestacy in Australia and New Zealand (Law Book Company, $2^{\text {nd }}$ ed, 1989) 496.

${ }^{59}$ Young v Young (Unreported, Supreme Court of Western Australia, Malcolm CJ, 26 April 1989) and Young v Young (Unreported, Supreme Court of Western Australia, Wallace, Pidgeon and Walsh JJ, 3 April 1990); McCallum v McCallum (Unreported, Supreme Court of NSW, Young J, 2 May 1986); Vigilo v Boston [2005] 221 CLR 191.

${ }^{60}$ For discussions about how women are often left out in family discussions about succession, in Judith Crockett, 'The Nature of Farm Succession in Three New South Wales Communities' (2004) 1(1) Australian Farm Business Management Journal 14; Denis Gamble et al, Transfer of the Family Farm Business in a Changing Rural Society (Rural Industries Report, Research Paper 95/8 1995). Note also the later discussion in this article of the Victorian Law Reform Commission Report, Succession Law: Report, 2013 discussed under heading III below.
} 
expectations through 'testamentary promises' that a son may inherit the farm in return for his years of labour. ${ }^{61}$

These cases reflect a conflict between the rewarding of sons who have worked on farms and the provision of maintenance for other children. In most cases, this conflict has been resolved in favour of the privileging of the farming sons' contribution over other children's needs. ${ }^{62}$ Other children (that is, non-farming sons and daughters) who help on the farm in various ways, who frequently attend to the nursing needs of invalid parents, ${ }^{63}$ and who have received promises by parents of reasonable provision, ${ }^{64}$ have in many cases received only meagre amounts, relative to the extent of their needs.

Percentage awards made to farming sons over the years indicate that such percentages of who gets what have not changed considerably. De Groot and Nickel calculate that prior to 1985, in typical orders, non-farming applicants received only 9.9 per cent of family property. After 1985, non-farm applicants received only 8.89 per cent. ${ }^{65}$ While these calculations are helpful, it must be noted that it is important to look at each case to observe the actual quantum given to siblings and widows or widowers and the amount given to children by way of gifts as forms of pre-inheritances.

In the mid-1980s, a few judgments in the courts of Western Australia seemed to commence a new approach, which has been modified by judgments in other states. ${ }^{66}$ This new approach in Western Australia rests on the notion that there

${ }^{61}$ See Giumelli v Giumelli (1999) 196 CLR 101; Bridgewater v Leahy (1998) 194 CLR 457; Ashton $v$ Pratt (No 2) [2012] NSWSC 3. For the treatment of a recent testamentary promise as regards a farming son, see Vigilo $v$ Bostin (2005) 221 CLR 191. For a recent case in Western Australia see Sidhu v Van Dyke [2014] HCA 19 (16 May 2014). As regards testamentary promises see Malcolm Voyce, 'Testamentary Promises, Family Provision and the Family Farm' (2014) 8 Elder Law Review 1.

${ }^{62}$ It is suggested here that it is a trend of the courts to recognise the male contribution, as generally there are few (if any) cases where a daughter has taken sole charge of a farm for a sequence of years.

${ }^{63}$ Young v Young (Unreported, Supreme Court of Western Australia, Malcolm CJ, 26 April 1989) and Young v Young (Unreported, Supreme Court of Western Australia, Wallace, Pidgeon and Walsh JJ, 3 April 1990).

${ }^{64}$ Wadley v Younger (Unreported, Supreme Court of Victoria, Southwell J, 10 October 1984); McCallum v McCallum (Unreported, Supreme Court of NSW, Young J, 2 May 1986); Vigilo v. Boston [2005] 221 CLR 191; Malcolm Voyce, 'Vigilo v. Bostin: Family Provision and Farming Sons’ (2005) 7(10) Retirement and Estate Planning Bulletin 149.

${ }^{65}$ De Groot, and Nickel, above n 6, 54-63.

${ }^{66}$ De Groot and Nickel assert that these Western Australian cases were just exceptional or not typical. See de Groot and Nickel, above n 6, 65. See Bondelmonte v Blanckensee [1989] WAR 305, which provided something of a corrective, see especially the judgment of Chief Justice 
was no general principle that competing interests should be discriminated against to assist the farming son to retain the farm. ${ }^{67}$ These Western Australian cases dealt with the general question of farm viability, the relevance to the claims of the fact that daughters are supported by their husbands and the relevance of gifts made to non-farming children. ${ }^{68}$

In Young $v$ Young, ${ }^{69}$ a case that involved these issues, the farm, which had been in the family for three generations, was bequeathed to the eldest son Gregory. Gregory had worked on the farm since leaving school at 15 years of age. During this time, he had received minimal wages. At the time of hearing, he had worked on the farm for 31 years. It had been the understanding between Gregory and his mother that he would inherit the farm. The late mother bequeathed the farm to Gregory while the daughters received only \$20 000 each from the will, to be distributed to them 10 years after their mother's death.

The testatrix had developed the strategy that the farm would be used as a resource, assisting one son to buy another farm and assisting the girls in their education. Eventually, in line with this plan, Gregory would inherit the farm. The two daughters who contested the will had helped on the farm from time to time. They had received some help from their family amounting to $\$ 7000$ each. At the time of the hearing, the daughters were married and in secure positions, although for a period of years earlier they had been unemployed or in casual jobs.

In the Supreme Court of Western Australia, Malcolm CJ considered that the will did constitute adequate provision for the daughters, and he awarded the farm (currently valued at $\$ 821000$ ) to Gregory, so that the two plaintiff daughters received no increase in their legacy of \$20 000.

\footnotetext{
Malcolm. This case has been followed by Vigolo $v$ Bostin (2005) 221 CLR 191 where the High Court emphasised the issue of need.

67 Two recent cases make it clear that there are no distinctions based on gender: Johnston $v$ McCallum [2005] NSWSC 17, 61 (Master Macready J) makes clear that where the needs of a claimant outweigh the need of those due to inherit the farm, the Court was prepared to make an order requiring the sale of the family farm. Likewise in Popovski $v$ Kenjar; Hafizovic v Kenjar, Hallen J commented that there is 'no distinction based on gender' [2011] NSWSC 731, [73] (Hallum AsJ).

${ }^{68}$ For a reported case in Western Australia with this latter emphasis, see Malcolm CJ in Bondelmonte $v$ Blanckensee [1989] WAR 305, 307. For decisions in NSW which give emphasis to support rather than other factors, see Hunter v Hunter (1987) 8 NSWLR 573, 575 (Kirby J) and Gorton v Parks (1989)17 NSWLR 1.

${ }^{69}$ Young v Young (Unreported, Supreme Court of Western Australia, Malcolm CJ, 26 April 1989) and Young v Young (Unreported, Supreme Court of Western Australia, Wallace, Pidgeon and Walsh JJ, 3 April 1990).
} 
In reviewing the case, Malcolm CJ said:

I am satisfied that it was very common in farming families to take the view that it was the moral duty of a testator or testatrix to discriminate between male and female children in certain circumstances. Where the male had forgone wages, worked on the farm and help build it up in the expectation of inheritance and the female children were supported by the family through their education to the point where they were qualified to obtain employment which would enable them to live comfortably and independently of the farm, the moral duty was discharged by the male inheriting the farm. This is such a case. ${ }^{70}$

The judgment was appealed to the Full Court of Western Australia. Here, Pidgeon J gave consideration to the extent that a wise and just testator would give a greater share to a son who had worked the farm for many years. He concluded that such a testator

would wish to make provision to preserve that farm even if it gives a greater benefit to the beneficiary conducting the farm. This would, a fortiori, be the position if the farm has been in the family for a number of generations. It would still be necessary to make provision for other members of the family. This is often achieved by making provision that there be annuities charged on the farm property. ${ }^{71}$

One of the applicant daughters' grounds of appeal to the Full Court was that for their mother to leave them only a legacy and to leave the farm to Gregory was sexual discrimination. Walsh $\mathrm{J}$ said in response to this claim:

It is clear from his reasons that his Honour balanced with care the competing moral claims of the children and, in doing so, was very careful to emphasise that discrimination between sons and daughters was not a determinative factor. He did have regard, no doubt, to whether the farm, which had been in the family for three generations, should be kept as an indivisible entity. This, however, was only one of the circumstances which he took into account in his careful assessment of all the relevant factors. ${ }^{72}$

Young $v$ Young is a representative case that makes it clear that where a farming son has contributed to a farm, the son will be allowed to inherit the farm as part

\footnotetext{
${ }^{70}$ Young v Young (Unreported, Supreme Court of Western Australia, Malcolm CJ, 26 April 1989) 32 (emphasis added).

${ }^{71}$ Young $v$ Young (Unreported, Supreme Court of Western Australia, Wallace, Pidgeon and Walsh JJ, 3 April 1990) 6 (emphasis added).

${ }^{72}$ Young $v$ Young (Unreported, Supreme Court of Western Australia, Wallace, Pidgeon and Walsh JJ, 3 April 1990) 26-7.
} 
of the general carve up of the estate, provided that necessary provision has been made for other children. The fact that the farm had been in the family for a number of generations was indicated to be only one factor that a judge should take into account. Furthermore, the case made clear that the legislation is not concerned with assessing the contribution of the parties to the property, but in assessing need. In this regard the bench considered that the daughters were not in need of further support.

On one level, the farming sons cases reflect the sociology of rural life - the decline of rural towns, rural depopulation, especially of women eligible for marriage, ageing farming populations and a decline in education and health. Another facet of these cases reflects the socialisation of children into gender roles, in a socio-cultural field where gender positions are constructed in hierarchical ways, where men are constructed as strong and tough and women as peripheral. ${ }^{73}$ One prominent feature of these cases is their failure to recognise that girls helped on the farms in their childhood and, in adulthood, looked after ageing parents. ${ }^{74}$ At the same time, farming sons get the benefit of numerous tax advantages and drought relief measures, while they have the benefit of farm accommodation. These factors are 'hidden benefits' which are often not taken into account when wills are contested.

\section{E Recent Cases on Farming Sons}

In the conclusion to this part of the discussion, some recent cases will be considered which demonstrate the continuance of special consideration given to farming sons. ${ }^{75}$

The judgments in these cases state the principle that farming sons do not get special treatment. However, the share that these sons actually receive in the cases is notable and worthy of comment, as indicated above. Taking into account all the discretionary factors laid down by the legislation, the amount an inheriting son receives is considerable.

\footnotetext{
${ }^{73}$ Ruth Leipen, 'Making Men: The Construction and Representation of Agriculture-Based Masculinities in Australia and New Zealand' (2000) 65(4) Rural Sociology 605.

${ }^{74}$ These features of rural life have been well reported by Alston, 'Farm Women and Their Work', above n 11, 23; Alston, 'Who Is Down on the Farm?' above n 8; Alston, 'You Don't Want to Be a Check-Out Chick All Your Life: The Out Migration of Young People from Australia's Small Rural Towns' (2004) 39(3) Australian Journal of Social Issues 299. An important study on the socialisation into gender roles is Ulrike Schwarz, 'To Farm or Not to Farm': Gendered Paths to Succession and Inheritance (LIT Verlag, 2004).

${ }^{75}$ De Groot and Nickel, above $n 6$.
} 
For instance, in Monshing ${ }^{76}$ the value of the estate was $\$ 1.4$ million. In the will, one son received 49 per cent of the estate and the other son received 31.5 per cent. One daughter received 10 per cent and the other daughter received 8.5 per cent. Both sons had worked hard and long on their respective farms which were part of the overall property of the estate. The daughters were both impoverished and without assets. The judge, on hearing these facts, apportioned the estate in such a way that one son received 40 per cent, the other son received 25 per cent and both daughters received 17.5 per cent each.

In Torney $v$ Shalders ${ }^{77}$ the deceased left a farm worth $\$ 2.45$ million to her son, who already held substantial assets. The three daughters received about \$115 000 each under the will. The judge awarded the daughters more money so that two daughters received \$215 000 each while one received \$310 000. The son's strong claim was based on the fact of his having worked on the farm for the whole of his life and his reasonable expectation that he would inherit the farm properties. Also taken into consideration was his low income, his responsibilities to his child, and his need to operate all or most of his farms to maintain his income.

Here the judge looked for a creative solution in order that part of the farm did not have to be sold and the daughters could receive substantial monetary legacies. The court was satisfied that, given the son's 'substantial independent asset position', he would be able to satisfy a future mortgage on the assets without having to subdivide or sell the farm property. Nevertheless, the daughters overall received only a small interest in the deceased's assets, amounting to 10 per cent in total between them.

These recent judgments continue to uphold the position that farming sons do not have a special right to receive the family farm. However, when an evaluation is made, as above, of what farming sons receive in percentage terms as against other claimants, it may be suggested that the outcomes of these various cases are not as they have been described within academic literature. ${ }^{78}$ The academic literature elaborates in general terms the principles of family provision law, whereas these principles really need elaboration through an explanation of the actual percentage awards made in individual cases.

\footnotetext{
${ }^{76}$ Re Monshing (dec'd); Hobley v Stevenson [2003] VSC 498 (19 December 2003).

${ }^{77}$ Torney $v$ Shalders [2009] VSC 268.

${ }^{78}$ An exception is de Groot and Nickel, above $\mathrm{n} 6$, who very usefully show percentages on the awards made to the various classes of applicants. Note that not all commentators agree with the way these tables have been formulated.
} 


\section{F An Overview of Recent Cases}

It is suggested here that judgments dealing with farms and family provision make the following clear, both in terms of stated principle and in terms of actual results.

First, there is no principle that farming sons have a right to inherit the farm to the detriment of the claims of other children. ${ }^{79}$ However, the cases show a pattern that coincides with the strong rural norm that sons should inherit the family farm, provided that other members of the family are well provided for.

Second, where a property has been in the family for a number of generations, and non-farming children have not been adequately provided for, consistent with the above statement, the other children will not be allowed to suffer detriment. The fact that the farm has been in the family for a number of generations is, at best, only one of the factors a judge will take into account. ${ }^{80}$

Third, there is a strong Australian rural traditional attitude that widows should be supported and maintained. Such a widow, we might imagine, has borne the testator's children, lived on the farm with him for many years and helped him in his declining health. ${ }^{81}$ However, this rule is not of universal application; it is now conceded that it depends on the circumstances. ${ }^{82}$

Fourth, family provision legislation is not aimed at achieving equality among descendants. The criterion used in the legislation is not whether or not the will is fair, or why the testator did not divide her property equally. The question is has the testatrix by her will 'failed in her moral duty to those who had a claim on her'. ${ }^{83}$

In Murphy $v$ Murphy, King $\mathrm{J}$ acknowledged that there had been a tendency in that case to argue that the testator's sons had been treated unequally: that the

\footnotetext{
${ }^{79}$ This is clearly the case as the emphasis is always on the need of the applicant/s.

${ }^{80}$ In Roberts $v$ Roberts in the Full Court, Seaman J left open the question of the significance in family provision cases of a testator's attachment to real property by 'by virtue of his own or his forebears' connection with it': (1992) 9 WAR 549, 561. See also Worthington $v$ Dickson (Unreported, Supreme Court of Western Australia, Brinsden J, 1 June 1984).

${ }^{81}$ Cunningham v Cunningham [1936] GLR419; Re Lipscomb [1963] NSWLR 1509; King v White [1992] 2 VR 417, 423. See De Groot and Nickel, above n 6, 88-9; Dal Pont and Mackie above $n$ 6, 579-84.

${ }^{82}$ Bladwell v Davis [2004] NSWCA 170 [12] (Bryson JA).

${ }^{83}$ Stewart $v$ McDougall (Unreported, Supreme Court of NSW, Young J, 19 November 1987) 5 on the Family Provision Act 1982 (NSW). See also Re Hokin [1959] VR 711, 714 (O’Bryan J); Gorton v Parks (1989) 17 NSWLR 1, 6-7 (Bryson J).
} 
defendant had received more than his fair share of the estate. The judge observed, 'this is not the object of Pt IV proceedings. The Act does not empower the Court to make a new Will for the testator on the basis of general considerations of fairness' ${ }^{84}$

The Acts have been interpreted to give no licence to a court to mandate a fair or equitable disposition of the deceased's estate but instead to require that an 'adequate' or 'proper' provision be made. The language of the various Acts clearly upholds a differential treatment of family members where that is considered appropriate. ${ }^{85}$

Last, married daughters are often denied awards because they have married well. A feature of the majority of cases is that married daughters who made applications have been considered sufficiently well maintained and not in need of support if their husbands are not in need of support. This reflects the idea of women as 'dependent' on the husband who could be relied on as the primary earner in the relationship. The effective result is that, when a daughter is not substantially provided for, the rest of the estate is released to help establish the male. The best outcome that married women can expect from the courts is that they will be considered when they have need. ${ }^{86}$

These cases show that, as regards the balance between farming continuity and support for other children, the pendulum has swung to the central belief that adequate support (maintenance) must be provided for all children, rather than the belief that sons must be rewarded for their contributions. Recently the High Court has affirmed that the duty of the testator is a 'moral duty' that must be assessed in terms of need. ${ }^{87}$ Consistent with the above principles, even where a son has built up a farm, or other children have been provided for by way of education, these circumstances will not be so weighted that they will deprive other children of adequate provision. However, this evaluation needs to take into account the actual percentage received by such sons. Different courts may evaluate the percentages in different ways.

\footnotetext{
${ }^{84}$ Murphy v Murphy (Unreported, Supreme Court of Victoria, King J, 16 October 1986) 11.

${ }^{85}$ Allardice; Allardice v Allardice (1910) 29 NZLR 959, 959 (Cooper J). See discussion in Dal Pont and Mackie, above n 6, 493-4.

${ }^{86}$ Hunter v Hunter (1987) 8 NSWLR 573; Goodman v Windeyer (1980) 144 CLR 490, 498; Blore v Lang (1960) 104 CLR 124.

${ }^{87}$ Vigolo v Bostin (2005) 221 CLR 191.
} 


\section{Family Provision LaW ANd RURAL Ways}

Farmers have a variety of views about land ${ }^{88}$ and whether or not the farm should be retained by the family after the death of the parents. ${ }^{89}$ Two attitudes to farming stand in contrast to each other: 'farming as a way of life' and 'farming as a business'.$^{90}$ In both cases, farmers may wish the farm to be maintained within the family by a child taking over the property after a period of apprenticeship.

Farming families sometimes cannot resolve internal conflict over how the farm should be dealt with after the death of a parent, and resort to litigation. While, as shown in this article, farming sons overall have been well rewarded in such

${ }^{88}$ For instance, on the history of 'squatting' of great areas of grazing land in Australia and how graziers claimed that occupation itself created a form of tenure, see Stephen $\mathrm{H}$ Roberts, The Squatting Age in Australia 1835-1847 (Melbourne University Press, 1935). These views may be contrasted with the 'yeoman model' of land settlement and the notions 'closer settlement' and later with 'soldier settlement'. See Joseph Powell, A Historical Geography of Modern Australia: The Restive Fringe (Cambridge University Press, 1988); Stuart Macintyre, Winners and Losers: The Pursuit of Social Justice in Australian History (Allen \& Unwin, 1985); Perry O'Brien Share, 'Tickle It with a Hoe and It Will Laugh with a Harvest'! Discourses of Closer Settlement in Australia 1898-1988 (Doctoral thesis, School of Sociology and Anthropology, LaTrobe University, 1994).

${ }^{89}$ Trevor Webb, John Cary and Paula Geldens, 'Leaving the Land: A Study of Western Division Grazing Families in Transition' (Rural Industries Research and Development Corporation, 2002). It is accepted also that some farming sons show strong views against taking on the family farm, especially in dairy areas: J H Bell and J S Nalson 'Occupational and Residential Mobility of Ex-Dairy Farmers on the North Coast of New South Wales. A Study of Alternative Occupations (Department of Sociology, University of New England, Armidale, 1974); Roger Lindsay Wilkinson, Population Dynamics and Succession Strategies of Rural Industry Producers (Doctoral Thesis, Institute for Sustainability and Innovation, Victoria University, 2009).

${ }^{90}$ Wilkinson noted that there were two views amongst the family farmers he interviewed in his study of northern Victoria. Some farmers regarded the farm as a piece of heritage and the other view was that the farm was an asset like any other, which could be manipulated and sold. See Wilkinson, above n 89. See also Webb, Cary and Geldens, who noted that pastoralists had a strong attachment to their property as a place and that such pastoralists expressed notions of independence, physical pride and the ideal of passing on of the family farm: Webb, Cary and Geldens, above n 89. Kerridge noted that the large-scale farmers had instrumental values about the farming business while small-scale farmers' exhibited values ideas about lifestyle and independence and were unlikely to respond to adjustment incentives: see K W Kerridge, 'Value Orientations and Farmer Behaviour-An Exploratory Study' (1978) 31(1) Quarterly Review of Agricultural Economics 61, 67-70. See studies in rural sociology, which discuss different farming styles or strategies, eg, Jan Douwe van der Ploeg, 'Styles of Farming: An Introductory Note on Concepts and Methodology' in Jan Douwe van der Ploeg and Ann Long (eds), Born from Within: Practice and Perspectives of Endogenous Rural Development (van Gorcum, 1995) 7; Frank Vanclay et al, 'The Social and Intellectual Construction of Farming Styles: Testing Dutch Ideas in Australian Agriculture’ (2006) 46(1) Sociologia Ruralis 61. Some farming sons show strong views against taking on the family farm, especially in dairy areas: see Roger Wilkinson, 'Leaving Farming: The Experiences of Some Northern Victorian Families’ (unpublished manuscript). 
cases, the results of such litigation do not necessarily reveal the full picture as regards the social position of rural families. It is relevant to consider whether, and if so what, extra-judicial factors should be taken into account.

In his study on the sociology of the forms of dispute settlement Galanter suggests that different forms or levels of informal dispute settlement exist alongside official systems. ${ }^{91}$ He describes a range of ways of solving disputes, which may operate along a continuum, from an official system to a private remedy system. He sees one form as an 'appended' system, which, while it merges imperceptibly into the official system, is practised through family negotiations and local power structures. ${ }^{92}$

Should we apply this approach to family provision law? It is suggested here that there are facets of rural culture, ${ }^{93}$ which act as an 'appendage' or 'ancillary forum', which in turn operates alongside family provision law. Family provision law overlaps, interlocks with, and feeds into rural culture. To establish this argument, five points can be made by way of conclusion.

First, in Australia there has always been a view, strongly held by farmers, that the exploitation and development of farming lands give ownership rights. Like farmers elsewhere, Australian farmers justify their land ownership in terms of Lockean notions of exploitation and development, although of course farmers may never have heard of such theories. ${ }^{94}$ The cases of farming sons reflect a long-held notion that those who toil and suffer on the land should be rewarded with inheritance, to the detriment of off-farm children.

Second, it is claimed that succession law and the principle of testamentary freedom leave testators free to decide who inherits property. For instance, West

\footnotetext{
${ }^{91}$ Mark Galanter, 'Why the "Haves" Come Out Ahead: Speculations on the Limits of Legal Change' (1974) 9 Law and Society Review 95, 124-30.

${ }^{92}$ Ibid 126-30.

${ }^{93}$ It must be recognised, of course, that rural culture or 'rurality' is considerably more unstable, diverse, contested and fragmented a phenomenon than we may assume. It is easy to falsely compress a diverse cultural reality into a single uniform template; see comments by Russell Hogg and Kerry Carrington in Policing the Rural Crisis (Federation Books, 2006) 7.

${ }^{94}$ For a discussion of Lockean notions in Australian lands settlement, see Malcolm Voyce, 'Ideas of Rural Property in Australia' in Geoffrey Lawrence, Kristen Lyons and Salim Momtaz (eds), Social Change in Rural Australia (Central Queensland University, 1996) 95; Lenore Coltheart, Australia Misere: The Northern Territory in the Nineteenth Century (Doctoral thesis, Griffith University, 1982); Duncan Waterson, Squatter, Selector and Storekeeper: A History of the Darling Downs, 1859-1893 (Sydney University Press, 1968). As regards John Locke see Peter Laslett (ed), Two Treatises of Government by John Locke (Cambridge University Press, 1960); Neil Wood, John Locke and Agrarian Capitalism (University of California Press, 1984).
} 
argues that, despite legal reforms, ${ }^{95}$ legislation has had little effect on the power relationships between fathers and sons, and mothers and daughters. She argues that patriarchal forces have created 'zones of protection' where patriarchy is free to operate' ${ }^{96}$ Fellows argues in a similar way - that under the umbrella of privacy and family autonomy the law creates a 'zone of protection' within which rural patriarchal forces 'are left intact'. ${ }^{97}$ Are these American views representative of the Australian position?

Several recent academic studies reveal how entrenched patriarchy is in rural farming families. Wives and daughters consider themselves sidelined in the farm transfer process as they feel they are not consulted. These studies reveal that the fathers frequently do not discuss inheritance issues, and children, especially girls, feel that they are not 'part of the conversation'. ${ }^{98}$

Research indicates that most farming parents prefer a male successor. A survey by Barclay and Reeve has indicated that parents prefer a son to inherit the property. ${ }^{99}$ This study indicated that over half (51.6 per cent) of the respondents reported that they had identified a male successor to take over the farm. Only 10 per cent of the successors nominated were daughters while two per cent were sons-in-law.

Other studies suggest that traditional attitudes, which regard farming as a male concern, have not shifted to any large degree. ${ }^{100}$ The awarding of family

${ }^{95}$ Such as family provision legislation or the Family Law Act 1975 (Cth).

${ }^{96}$ Robin West, 'Feminism, Critical Social Theory and Law' (1989) University of Chicago Legal Forum 59, 65.

${ }^{97}$ Mary Fellows, 'Wills and Trusts: The Kingdom of the Fathers' (1991) 10 Law \& Inequality Journal 137, 145.

${ }^{98}$ Crockett, above n 60; Gamble et al, above n 60.

99 Elaine Barclay, Ian Reeve and Rosyln Foskey, 'Australian Farmers' Attitudes towards Succession and Inheritance', in Matt Lobley and John Baker (eds), Keeping It in the Family, International Perspectives on Succession and Retirement on Family Farms (Ashgate, 2012) 21-36.

100 This is a well-researched topic amongst rural sociologists in Australia, who have indicated that there is a shift in the position of women in agriculture, typified by a trend for women to take up outside employment and to own their own farms. At the same time, more children are taking up tertiary education and there is a greater diversity in business structures. Evidence suggests this shift may not have affected rural patriarchy as regards the devolution of family property: see Alston, 'Farm Women and Their Work' above n 11; Alston, Breaking through the Grass Ceiling, above n 11; Alston, 'Who Is Down on the Farm?', above n 8; Alston, 'You Don't Want to Be a Check-Out Chick All Your Life', above n 74; Lia Bryant and Barabara Pini, Gender and Rurality (Routledge, 2011); Barbara Pini, 'Farm Women: Driving Tractors and Negotiating Gender' (2005) 13(1) International Journal of Sociology of Agriculture and Food 1; Barbara Pini, 'Always an Outlaw: Daughters-in-Law on Australian Family Farms' (2007) 30(1) Women's Studies International Forum 40; Barbara Pini and Sally Shortall, 'Gender 
property to sons coincides with a rural distributive ideology that work done by a son on a farm over a series of years should lead to his eventual inheritance of the farm, and that a parent should honour a promise that the son should inherit the farm. ${ }^{101}$

A recent report by the Victorian Law Reform Commission - Succession Laws ${ }^{102}$ - helpfully provides a glimpse into the background of such inheritance disputes. This report affirms the strength of the male claim to inherit the farm. At the same time, the submissions reveal the converse - that applicant daughters (and perhaps other non-landed sons) do not regard themselves as receiving a fair share of farm property. This fact, of course, increases the anguish of farming sons who do not inherit family land.

One submission by the Victorian Farmers Federation expresses the concern that testamentary freedom is being restricted as family provision laws 'encourage vexatious or stab-in-the-dark' claims that would in most cases be contrary to the deceased wishes' ${ }^{103}$ in most cases be contrary to the deceased's wishes. Finally, the submission contends that independent children should not have a claim for support, and that successful applicants for further support should satisfy a needs test to prove that they cannot support themselves. ${ }^{104}$

Third, the traditional rule based on the law of trusts is that, in the case of a life interest being bequeathed to a widow, the life tenant receives only the income from the estate and cannot deplete the capital. ${ }^{105}$ This rule relegates the woman to a vessel or conduit between successive generations. This rule coincides with

Equality in Agriculture: Examining State Intervention in Australia and Northern Ireland' (2006) 5(2) Social Policy \& Society 199.

101 Crockett, above n 60, 14; Gamble et al, above n 60. The cases on testamentary promises are instructive as they indicate family disharmony and the variety of views about who should get what, and especially the strength of male views on the righteousness of work. See especially McCallum v McCallum (Unreported, Supreme Court of NSW, Young J, 2 May 1986) and Vigilo v Boston (2005) 221 CLR 191. See also the comments by the son in this case in the Australian Broadcasting Commission, 'Farms, Families and Fights over Wills', The Law Report, Radio National, 12 April 2005 (Virginio ‘Gino’ Vigoli).

102 Victorian Law Reform Commission, Succession Laws: Report, 2013.

103 See Peter Tuohey, Victorian Farmers' Federation, Submission No 41 to Victorian Law Reform Commission, Succession Laws, 4 January 2013.

104 Ibid 3.

${ }^{105}$ Malcolm Voyce, 'Governing from a Distance: The Significance of the Capital Income Distinction in Trusts', in Susan Scott-Hunt and Hilary Lim (eds), Feminist Perspectives on Equity and Trusts (Cavendish Publishing, 2001) 153. 
a common rural attitude that a woman deserves only maintenance during her widowhood, without any right to ownership of capital. ${ }^{106}$

These rural values endorse the ideology that farming sons should inherit rural property: in other words, that work on property should be exchanged for title deeds. These values exist alongside a conceptualisation of women as having the status of farmer's helpers. This culture exists across generations. Men are socialised as a 'farmer's son' and women have little opportunity to inherit the farm or learn the skills of farming. In this culture, daughters learn to be the supporters of farmers as farming men move through the life cycle of 'farmer's son', 'boss farmer' and 'retired farmer'. ${ }^{107}$

Submissions to the Victorian Law Reform Commission reveal further aspects of will contests that need comment here. Most states now have compulsory mediation procedures. ${ }^{108}$ One legal practitioner has estimated that 'almost all such claims are resolved at the point of mediation. ${ }^{109}$ It is generally observed that settlement may not be based on the merits of a case but on the need for an outcome that satisfies all the parties. ${ }^{110}$ A son's share of the estate may be less than a court would have awarded, such share being further reduced by the legal costs involved. This means that the decided cases where percentages are calculated do not necessarily reflect the majority of outcomes. ${ }^{111}$

\footnotetext{
106 Older cases indicate this attitude: see William Patterson, The Law of Family Protection and of Testamentary Promises in New Zealand (Butterworths, 1985) 163. Newer cases support the proposition that a redistribution of an estate will be made if it is necessary for the support of a life tenant: see Permanent Trustee Co Ltd v Fraser (1995) 36 NSWLR 25, 47; Woolnough v Public Trustee [2005] TASSC 50.

${ }^{107}$ Linda Price, 'Rural Support Networks in the UK and Canada: The Influence of the Patrilineal Culture of Family Farming' (Working Paper No 3, Institute of Spatial and Environmental Planning, School of Planning, Architecture and Civil Engineering, Queen’s University, Belfast, 2011) 131.

${ }^{108}$ See eg Succession Act 2006 (NSW) s 98.

109 Victorian Law Reform Commission, Succession Laws: Report, 2013, 100 [6.12]. The same Report observed that in the Supreme Court of Victoria, as recorded in its annual report, of the 65 mediations in 2011-12, 59 were settled: at 125 [6.141].

${ }^{110}$ Victorian Law Reform Commission, Succession Laws: Report, 2013, 100, 125.

${ }^{111}$ See Daniels v Hall (as Administrator of the Estate of Arnold Edward Daniels) [No 2] [2014] WASC 272 (29 July 2014) for a reminder that costs do not always come out of the estate. An unsuccessful adult son was ordered to pay the costs of both the executor and the separately represented beneficiaries.
} 


\section{CONCLUSION}

The predominant values of family farmers continue in general to reflect gendered ideas of labour, including the idea that sons should inherit the family farm. The enactment of family provision legislation has done little to change this persistent cultural pattern. Thus, while it has been reaffirmed in recent years that the moral duty of the testator must be assessed in terms of the 'needs' of children, farming sons continue to receive the largest share of family assets. 